\title{
A True Hybrid Solar Wind Turbine Electric Generator System for Smaller Hybrid Renewable Energy Power Plants
}

\author{
Mohammad Shafi Al-Ajmi ${ }^{1}$, Faizal Mustapha ${ }^{2}$, Mohd. Khairol Anuar b. Mohd Ariffin², Nurul Amziah Md. Yunus ${ }^{3}$, \\ Izhal Abdul Halin ${ }^{3 *}$ \\ ${ }^{1}$ Ministry of Electricity and Water, Department of Electrical Distribution Networks (Jahra), Kuwait \\ ${ }^{2}$ Universiti Putra Malaysia, Department of Aerospace Engineering, Selangor, Malaysia \\ ${ }^{3}$ Universiti Putra Malaysia, Department of Electrical and Electronics Engineering, Selangor, Malaysia
}

\begin{abstract}
Contemporary Hybrid Solar-Wind farms are implemented using separate solar Photovoltaic (PV) cell arrays and wind turbines, where electricity generated from both devices are combined. However, this solution requires a large amount of space to cater for the PV arrays and wind turbines of the system. This paper proposes a new type of renewable energy electric generator with a small power production footprint (PPF) that allows reduction in land usage. The technology introduced in this True Hybrid Wind-Solar (THWS) generator allows for the solar panels to rotate along with a VAWT wind turbine it is attached to through a specially designed electromechanical coupling mechanism. The working principal behind the connections described in this paper. The design of a hybrid circuit module that serves to combine current generated via the solar cells and wind generator and also automatically disconnects inactive wind or solar generators is also described. This is important in order to eliminate unwanted loads generated from the inactive generators from within the THWS itself.
\end{abstract}

\section{Introduction}

In the past decade, the world has seen an exponential increase in energy demand. Fig 1. shows the source of actual energy consumption from 1990-2015 and its projected path from 2016 to 2040 [1]. This ever increasing trend is due to population growth of the world.

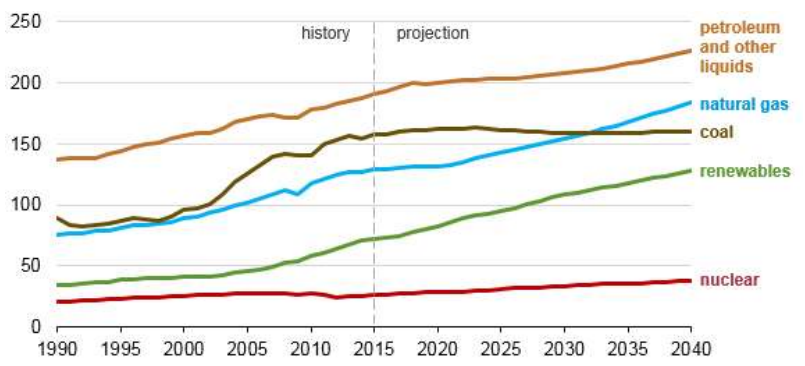

Fig. 1. Energy Demand Trends [1].

Simple analysis of Fig.1 shows that since 1990, the average energy demand from petroleum, natural gas and coal has risen by approximately 50 Quadrillion Btu at the end of 2017. Along with this unprecedented increase, a side effect of $\mathrm{CO} 2$ emission has also risen to levels of public concern [2] leading to Carbon taxation policies in the developing and developed nations[3].In contrast, it is observed that from 1990 to 2007, the demand for renewable energy is almost stagnant. However, from 2008 , the rate has increased to approximately 2.63 Quadrillion Btu/year and is comparable to the rate of increase in the demand of petroleum and natural gas. This increase in the popularity of renewable energy sources during this period is due to its ability to mitigate $\mathrm{CO} 2$ emission problems as well as advancement in technology for producing renewable energy. For example, a study conducted in Thailand predicts that that the use of solar and wind as a means of electricity generation will in approximately 50 years lower CO2 emission by $69.66 \%$ [4].

The sources of renewable energy available today include solar, wind, biomass, ocean tides, geothermal, hydro power and etc [5]. Although all of these sources are able to produce electricity with zero or negligible $\mathrm{CO} 2$ emission, solar and wind generation methods are the most popular. For example, unlike ocean tide electric generators that must be built near the ocean, solar and wind farms can be implemented almost anywhere. Similarly, this is why solar and wind are preferred to when compared to geothermal and hydro power generation. However, the area required to produce solar or wind energy is extremely large. This will bring forth socioeconomic issues such as lack of land for agriculture and housing.

\footnotetext{
* Corresponding author: izhal@upm.edu.my
} 
This paper proposes a new renewable energy generating device that utilizes both solar and wind energy for the production of electricity in one embodiment. The main objective behind the design objective is to minimize the area required when an array of this new hybrid generator is used for large scale RE power generation.

\section{Solar, Wind and Hybrid Wind-Solar}

\section{Farms and Land Area Usage}

Along with the rise in world demand for energy from renewable sources, a multitude of information is easily obtained concerning operators of large scale solar, wind and hybrid wind-solar energy for the public. These corporations have a public obligation to inform the public on the specifications of their plants. Table 1 shows five operational large scale solar power plants.

Table 1. Operational Large Scale Solar Power Plants.

\begin{tabular}{|c|c|c|c|c|c|}
\hline Reference & $\begin{array}{c}\text { Operation } \\
\text { Start Year }\end{array}$ & Location & $\begin{array}{c}\text { Number of } \\
\text { Panels } \\
\text { (million) }\end{array}$ & $\begin{array}{c}\text { Output Capacity } \\
\text { (MW) }\end{array}$ & $\begin{array}{c}\text { Area } \\
\left(\text { Hectar }^{2}\right)\end{array}$ \\
\hline$[6]$ & 2016 & $\begin{array}{c}\text { Kamuthi, } \\
\text { India }\end{array}$ & 2.5 & 648 & 1000 \\
\hline$[7]$ & 2017 & $\begin{array}{c}\text { Qinghai, } \\
\text { China }\end{array}$ & 4 & 850 & 300 \\
\hline$[8]$ & 2017 & $\begin{array}{c}\text { Kurnool, } \\
\text { India }\end{array}$ & 4 & $900 / 1000^{*}$ & 2352 \\
\hline$[9]$ & 2016 & $\begin{array}{c}\text { Datong, } \\
\text { China }\end{array}$ & NA & $1000 / 3000^{*}$ & NA \\
\hline$[10]$ & 2016 & $\begin{array}{c}\text { Ningxia, } \\
\text { China }\end{array}$ & NA & 1500 & 4300 \\
\hline
\end{tabular}

Note: * targeted capacity

It is clear that the area required is large to produce MW capacity plants. For example, the solar power facility in Kurnool with a targeted capacity of $1 G W a t t$ requires an area of 2,352 hectars ${ }^{2}$. Once a piece of land has been commissioned to build a mega scale solar plant, it is rendered unusable for agriculture and settlement for at least a 20 year period which is as long as powers purchase agreement. This is one of the disadvantages of large scale solar energy generation.

Table 2. Operational Large Scale Wind Power Plants.

\begin{tabular}{|c|c|c|c|c|c|}
\hline Reference & $\begin{array}{c}\text { Operation } \\
\text { Start Year }\end{array}$ & Location & $\begin{array}{c}\text { Number } \\
\text { of Wind } \\
\text { Turbines }\end{array}$ & $\begin{array}{c}\text { Output Capacity } \\
(\mathrm{MW})\end{array}$ & $\begin{array}{c}\text { Area } \\
\left(\mathrm{Hectar}^{2}\right)\end{array}$ \\
\hline$[11]$ & NA & Gansu, China & 7,000 & $6,000 / 20,000^{*}$ & NA \\
\hline$[12]$ & NA & $\begin{array}{c}\text { California, } \\
\text { USA }\end{array}$ & 750 & 3,000 & 12,950 \\
\hline$[13]$ & 1986 & $\begin{array}{c}\text { Tamil Nadu, } \\
\text { India }\end{array}$ & 3,000 & 1,500 & NA \\
\hline$[14]$ & 2001 & $\begin{array}{c}\text { Rajathan, } \\
\text { India }\end{array}$ & NA & 1,064 & NA \\
\hline$[15]$ & 2012 & $\begin{array}{c}\text { Oregon, } \\
\text { USA }\end{array}$ & NA & 845 & 20,720 \\
\hline
\end{tabular}

Table 2 shows five existing mega scale wind farms, their locations and output capacity. These farms are installed with large HAWT rated around the $1 \mathrm{MW}$ capacity each. Again it is seen that thea rea requirements is extremely high. For example, 12,950 hectars ${ }^{2}$ of land is required to produce $3 \mathrm{GW}$ from the facility in California [12]. This is mainly to adhere to safety regulations for placement distances between adjacent wind turbines.

Table 3. Operational Large Scale Hybrid Wind-Solar Power Plants.

\begin{tabular}{|l|c|c|c|c|c}
\hline Ref & Name/Location & $\begin{array}{c}\text { Solar } \\
\text { Cap. } \\
\text { (MW) }\end{array}$ & $\begin{array}{c}\text { Wind } \\
\text { Cap. } \\
\text { (MW) }\end{array}$ & $\begin{array}{c}\text { Total } \\
\text { Cap. } \\
\text { (MW) }\end{array}$ & $\begin{array}{c}\text { Area } \\
\text { (Acres) }\end{array}$ \\
\hline$[16]$ & SECI-NREDCAP/India & 120 & 40 & 160 & 1000 \\
\hline$[17]$ & Arena Gullen/Australia & 10 & 165.5 & 175.5 & 70 \\
\hline$[18]$ & Fakken Wind Farm/Norway & 20 & 54 & 74 & NA \\
\hline$[19]$ & Hero Future Energies/India & 28.8 & 50 & 78.8 & NA \\
\hline
\end{tabular}

Recently, several hybrid wind-solar power plants have also been reported and are shown in Table 3. Information on its respective solar, wind and total output capacity is presented. These hybrid plants have dedicated land to house PV cell arrays and wind turbines to produce electricity. Similar to the solar and wind RE plants, the area required to produce hybrid RE power is also quite large. However, when compared to pure large scale solar or wind farms, the usage of land for the generation of hybrid RE power is much more efficient since only 0.16 acres to 2.5 acres of land is required to produce a capacity of $1 \mathrm{MW}[16,17]$.

The use of large amounts of land for generating green power is seen as a social-economic problem because once a piece of land is commissioned for a large scale solar, wind or hybrid wind-solar power plant, it cannot be used for agriculture or residential purposes for a period of at least 25 years or is based on the period of a power purchase agreement between the RE power producer and the government where the plant is erected. The land requirement for generating RE energy is large due to the dimensions of the devices used to produce electricity. For example, the most efficient and well-designed large scale solar or wind farms require on average 4 acres of land to generate $1 \mathrm{MW}$ of electricity at full capacity [6-15].

\section{Available Hybrid Wind-Solar Generators}

PV cells produce electricity by means of the photovoltaic effect while wind generators induce electrical current in a coil by cutting a moving magnetic flux through the rotation motion of the propellers of the wind turbine [20, 21]. Contemporary hybrid wind-solar farms are designed by connecting a solar farm with a wind farm, making them also a clean source of renewable energy [22]. As discussed in the previous section, although energy production is clean, socio-economic impact due to the use of large amounts of land for long periods of time is also an unwanted effect of hybrid wind-solar plants. 


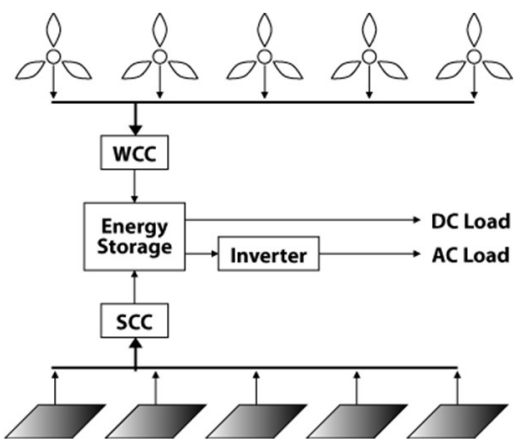

Fig. 2. Conventional Hybrid Wind-Solar Farm.

The simplified schematic of a conventional hybrid windsolar farm is shown in Fig.2. When the wind blows, the turbines generate DC current that is fed directly to the wind charge controller (WCC) and when the Sun is shining, the solar panels also generate DC current that is fed to the solar charge controller (SCC). Both of the charge controller's charges the system's battery. The battery's DC output is then fed to an inverter which converts it to an AC power signal. The AC signal is then fed to a transformer and stepped up according to specifications of the host grid. It is concluded that the conventional type hybrid plant uses dedicated solar panels and wind turbines to generate hybrid renewable energy.

A hybrid wind-solar generator on the other hand is defined as renewable energy device capable of generating electricity from wind power and solar irradiation in one embodiment. These devices are a combinatioin of either a Horizontal Axis Wind Turbine (HAWT) or a Vertical Axis Wind Turbine (VAWT) system coupled with Photovoltaic Cells. Hybrid wind-solar genrators have a combined capacity of its wind generating components and solar generating components and are placed stratigically at areas of high wind density and high solar insolution. Although not yet reported, these new hybrid RE generators are promosing devices when it comes to implementing high capacity hybrid wind-solar farms that use up a small area. Such a device was first introduced commercially in 2008 by a company called Windstream Technologies situated in India.

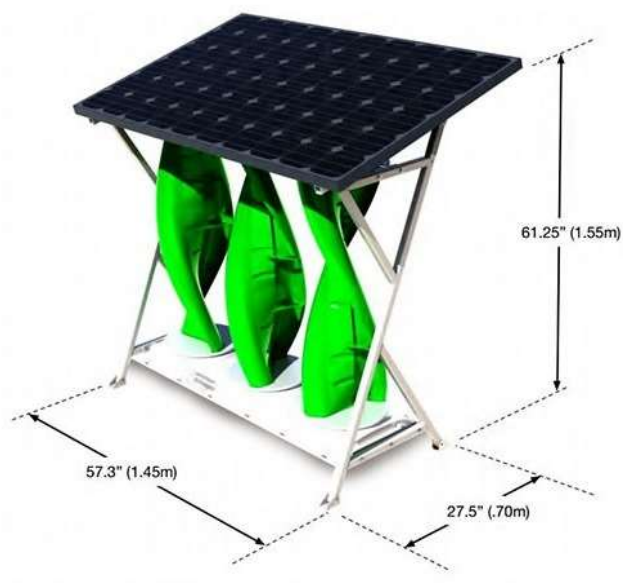

Fig. 3. SolarMill,SM1-1P [23].
As shown in Fig.3, the SM1-1P has a PV panel placed on top of a $3 \times 1$ array VAWT. It is noted that the PV panels are stationary. It generates at full capacity $740 \mathrm{~W}$ where $500 \mathrm{~W}$ comes from the VWAT system and the remaining 240W from its PV cells [23].

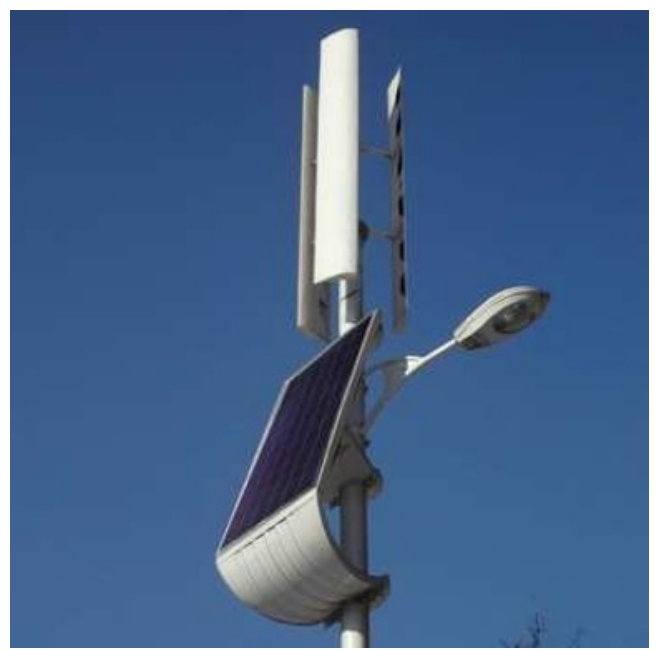

Fig. 4. TOYODA, TYD-WS4 [24].

Fig.4 shows another hybrid wind-solar generator from Tangsyan Toyoda Technology, China. Again, this device generates wind power using a VWAT system $(300 \mathrm{~W})$. A $240 \mathrm{~W}$ solar panel is mounted at the bottom of the wind turbine giving it a total capacity of $540 \mathrm{~W}$. It also houses a 100W street light [24].

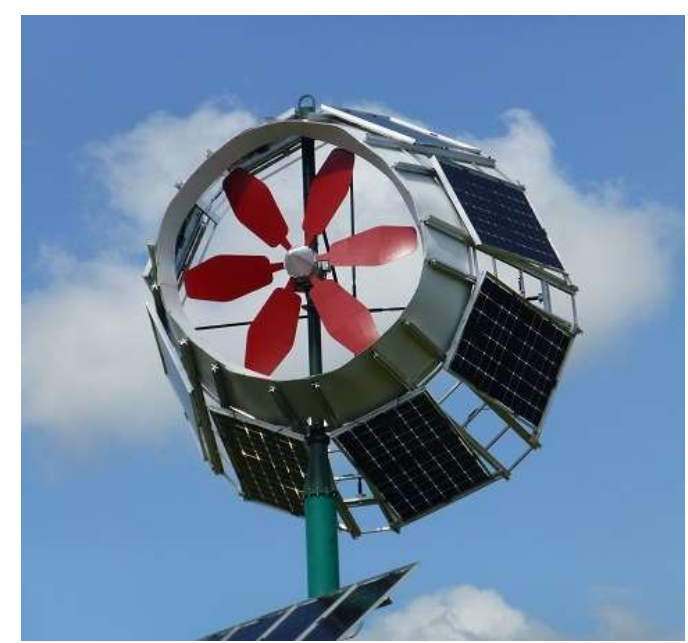

Fig. 5. SkyWolf [25].

Another hybrid wind-solar generator known as the SkyWolf is shown in Fig.5. This system's capacity is $3.5 \mathrm{~kW}$. It uses a Diffused Augmented Wind Turbine (DAWT) system where the turbine is enclosed in several solar panels arranged in a conic configuration to maximize rotation speed via the wind tunnelling effect. The turbine's angle can be rotated by computer control to maximize for optimum wind and solar generation [25].

It is concluded that these commercially available hybrid wind-solar generators have fixed solar panels. Through the course of a day, the temperature of these panels will 
rise causing its efficiency to drop. Moreover its capacity or footprint is too small, thus, a large area is required to arrange a large number of these devices to generate energy at a massive scale.

In this paper, we propose that rotating solar panels that move along with a wind turbines blade is to be used for the next generation of hybrid wind-solar generators. This will allow a much more compact device with high capacity. Moreover, the temperature of the PV panels are lower since the panels can rotate with the turbine's blade. In order to allow the solar panels to move in a circular motion with the blades.

\section{Proposed True Hybrid Wind-Solar Electric Generator}

The proposed True Hybrid Wind-Solar (THWS) Electric Generator is presented in Fig.6. Labels A, B and C are three different modules of the system are are called the Solar Blade Module (SBM), Moving Contact Module (MCM) and the Hybrid Output Module (HOM), respectively. This particular design is targetted for a total output capacity of $3.5 \mathrm{~kW}$.

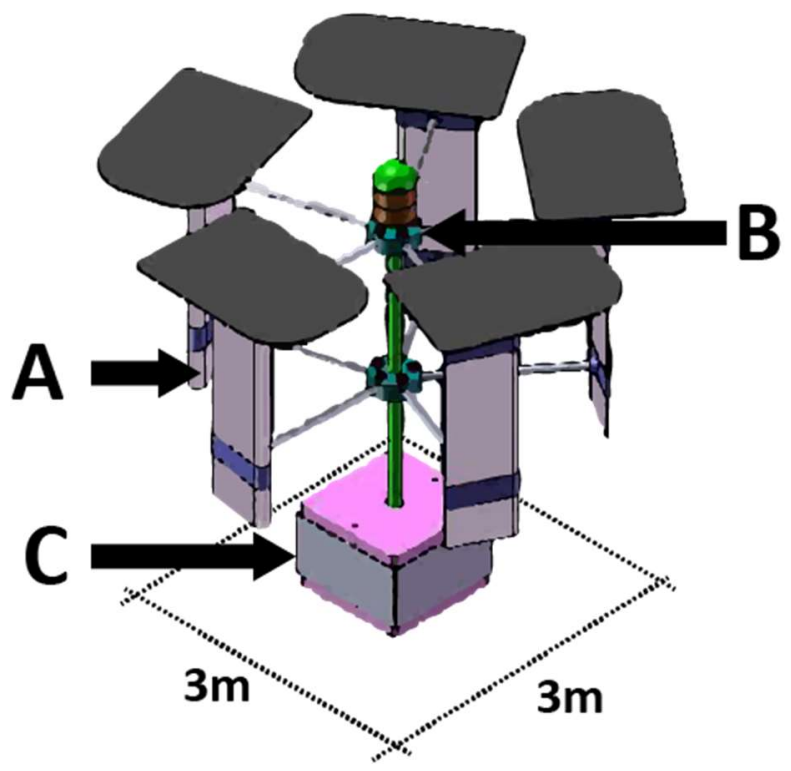

Fig. 6. True Hybrid Wind-Solar Electric Generator.

Each SBM is a modified Darrieus type blade where a $100 \mathrm{~W}$ PV panel is attached to a plate fitted perpendicular to the Darries type blade. Since there are five SBMs, the expected capacity is $500 \mathrm{~W}$. The size of the blade and dimensions of the THWS generator is determined by the dimension of the PV cells used. In general, a $1 \mathrm{~m} \times 0.5 \mathrm{~m}$ PV has a capacity of $100 \mathrm{~W}$, thus the THWS generator's footprint will $3 \mathrm{~m} \times 3 \mathrm{~m}$.

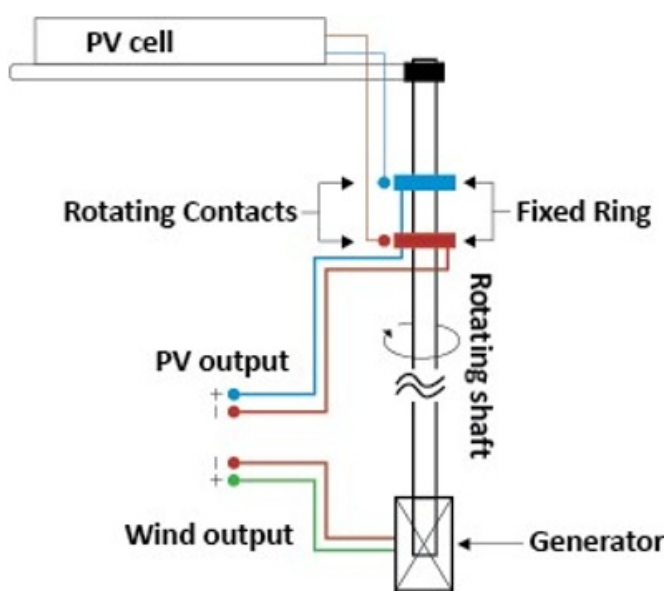

Fig. 7. True Hybrid Wind-Solar Modules Schematic.

Since all of the SBMs rotate, the problem of extracting the power signal produced by the PV cells is anticipated and the MCM is designed to tackel this problem. Fig. 7 shows the simplified circuit schematic of the TWHS generator. The MCM comprises of two fixed rings. The top fixed ring maintains connection from the PV cell's positive terminal to the PV cell output port of the THWS generator while the bottom ring does the similar for the negative terminal. The contacts of each respective PV output terminal orbits it's respective fixed ring as the SBM rotates in the wind. Electricity is tapped as the PV output terminal directly from the fixed ring with a voltage of $24 \mathrm{~V}$.

On the other hand, the HOM serves two purposes. The first is to generate electrical energy from the wind via the Generator shown in Fig.7. It is important to use a DC output generator for ease of combining solar and wind energy as the end product. A $3 \mathrm{~kW}$ capacity output is expected from a VAWT with a footprint of $3 \mathrm{~m} \times 3 \mathrm{~m}$ footprint of this design.

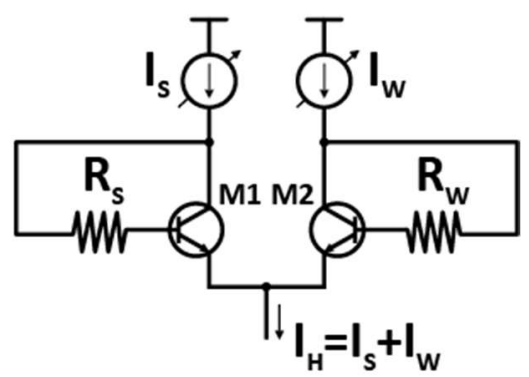

Fig. 8. Hybrid Power Selection Module.

The HOM's second purpose is to electrically isolate nongenerating RE generators within the THWS generator. For example, on a windy night, the PV cells are dormant, thus the HOM will electrically isolate all of the SBM from the system. This also acts to prevent loading from the PV cell's juntion capacitance onto the system. Fig. 8 shows the circuit contained in the HOM responsible for this task. Two power transistors, M1 and M2 capable of carrying $5 \mathrm{~A}$ currents are used. $\mathrm{I}_{\mathrm{S}}$ and $\mathrm{I}_{\mathrm{W}}$ denotes the solar and wind currents, respectively. A base resistance, $R_{S}$ and $R_{B}$ are 
connected to M1 and M2 in order to induce a voltage drop when $I_{S}$ and/or I $I_{w}$ are/is present. The generated voltage accross these resistances will turn on each respective transistor. When no voltage is induced, the transistor will turn off. In the case that the PV cells are not producing electricity, M1 turns off and $\mathrm{I}_{\mathrm{H}}=\mathrm{I}_{\mathrm{W}}$. When no wind is present, M2 turns off and $\mathrm{I}_{\mathrm{H}}=\mathrm{I}_{\mathrm{S}}$. However, when both PV cells and wind generator are producing current, both transistors are turned on, thus $\mathrm{I}_{\mathrm{H}}=\mathrm{I}_{\mathrm{S}}+\mathrm{I}_{\mathrm{W}}$.

\section{Estimation of the THWS Electric}

\section{Generator Power Production Footprint}

The Power Production Footprint (PPF) is defined for the first time in this work as the area required by a plant to produce $1 \mathrm{MW}$ of electricity. PPF can be used to measure the land usage efficiency for RE plants for monitoring socio-economic effects or simply as data for the planning of a large scale RE plants. In this paper, it is used to compare between the efficiency of land usage for a plant composed of THWS Generators and a plant composed of PV cell arrays or wind turbine generators.

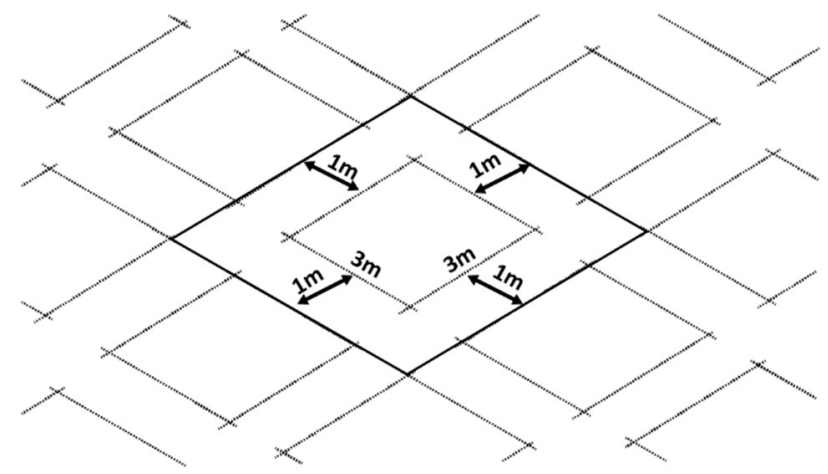

Fig. 9. THWS Generator Layout for Large Scale Power Plant.

Fig.9 is a depiction of the layout of several THWS generators arranged in a rectangular grid for the implementation of a large scale power plant. The raw footprint of one THWS is marked as $3 \mathrm{~m} \times 3 \mathrm{~m}$. To allow for safety and as a path for service and maintenance, it is suggested that the distance between two raw footprints is to be $1 \mathrm{~m}$. This results in a footprint of $3.5 \mathrm{~m}^{2}$ between two adjacent THWS generator units.

Since the capacity of one THWS generator is designed to be $3.5 \mathrm{~kW}, 290$ units are required to produce $1 \mathrm{MW}$. With a footprint of $3.5 \mathrm{~m}^{2}$, the total area required using the arrangement in Fig. 9 is $3552.5 \mathrm{~m}^{2}$ or equivalent to 0.88 acres of land. If a $20 \%$ more allowance is considered for other plant facilities such as transformers and inverters, the PPF of the THWS is approximately 1.06 acres/MW.

\section{Conclusion}

Analysis on area usage between large scale hybrid windsolar power plants and their counterparts, either large scale pure solar or wind plants shows that the hybrid RE plants have a much smaller PPF, making them much more area efficient. For example, the hybrid facility in Australia has a PPF of only 0.16 acres/MW [17]. However, these RE power plants use the traditional hybrid wind-solar topology where dedicated PV cell arrays and wind turbines are used separately to produce hybrid renewable energy. Nontheless, it is noted that hybrid type farms are more area efficient and in the long term will lower the negative socio-economic impact such as shortage of land for agriculture and housing.

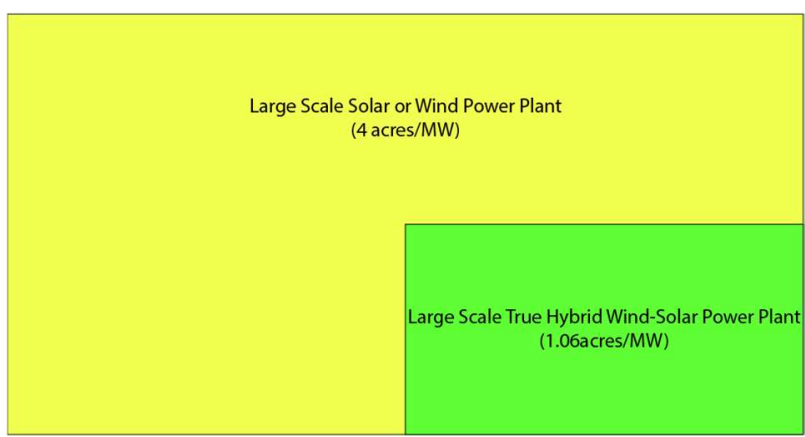

Fig. 10. THWS Generator Power Plant Land Size Comparison.

The recent emergence of hybrid wind-solar RE generators into the market have opened the opportunity for the development of large scale true hybrid wind-solar plants. However, either the generation capacity is too low or the PPF is too high in the existing models. Thus, the THWS electric generator is proposed in this paper. It is designed with a moving contact module that in the not so distant future will allow the blades of a wind turbine generator to be fabricated from PV material. In this work, placement of the PV cells in the porposed configuration not only allows a small PPF but also introduces a cooling effect to the PV panels which in turn boost the efficiency of the cells. The hybrid output is tapped out of the THWS generator via a dedicated HOM circuit. The THWS electric generator is designed for a $24 \mathrm{~V}$ output with solar capacity of $500 \mathrm{~W}$ and a wind capacity of $3 \mathrm{~kW}$ giving a total output capacity of $3.5 \mathrm{~kW}$ with a footprint of $3.5 \mathrm{~m}^{2}$. Arrangement of the THWS generator units in a rectangular grid will allow a PPF of only 1.06 acre/MW. As depicted in Fig.10, the PPF of a large scale THWS plant is approximately a quarter of the PPF of a conventional large scale solar or wind farm.

\section{References}

[1] British Petroleum (2016) BP Statistical Review of World Energy.London: Workbook (xlsx)

[2] Richard, S., Thomas, M.S. and Ruth, A.J., (2006) 'World Carbon Dioxide Emissions:1950-2050.' Review of Economics and Statistics, 80(1), 15-27 
[3] Intergovernmental Panel on Climate Change (2012) Renewable Energy Sources and Climate Change Mitigation : Summary for Policymakers and Technical Summary.Africa: IPCC

[4] Tri, V. K., usumadewi,Pornphimol, W. andBundit, L., (2017) 'Long-term CO2 Emission Reduction from Renewable Energy in Power Sector: The case of Thailand in 2050. ' Energy Procedia, 138, 961-966

[5] Antonia, V.H., Timothy, E.L., Jennifer, L.E. and Daniel, M.K., (2001) 'Renewable Energy: A Viable Choice' Environment, 3(10), 8-20

[6] Business Insider (2017) India has built the world's largest solar power plant - and it can power 150,000 homes, URL:http://www.businessinsider.com/india-hasbuilt-the-worlds-largest-solar-power-plant-2016-

$11 /$ ? IR=T (date accessed: 29November 2016)

[7] Alternative Energies (2017) Longyangxia Dam Solar Park in China is now the Biggest Solar Farm in the World, URL:https://www.alternative-energies.net/longyangxiadam-solar-park-in-china-is-now-the-biggest-solar-farmin-the-world/(date accessed: 19 January 2017)

[8] The Hindu (2017) With Kurnool solar park, State takes a giant leap, URL:http://www.thehindu.com/todayspaper/tp-national/tp-andhrapradesh/with-kurnool-solarpark-state-takes-a-giant-leap/article18289685.ece (date accessed: 29 Arpil 2017)

[9] Wikipedia (2017) List of photovoltaic power stations, URL:https://en.wikipedia.org/wiki/List_of_photovoltaic power_stations (date accessed: 24April 2018)

[10] ESCN (2016) Ningxia builds the largest desert photovoltaic integrated area in the southern edge of the Tengger Deser, URL: http://www.escn.com.cn/news/show-310093.html (date accessed: 5 Arpil 2016)

[11] The New York Times (2018) It Can Power a Small Nation. But This Wind Farm in China is Mostly Idle, URL:

https:/www.nytimes.com/2017/01/15/world/asia/chinagansu-wind-farm.html (date accessed: 15 January 2017)

[12] Inside Climate News (2009) Alta Wind Farm, America's Largest Wind Power Project, Blows Closer, URL: https://insideclimatenews.org/news/20090727/altawind-farm-america $\%$ E2\%80\%99s-largest-wind-powerproject-blows-closer (date accessed: 27 July 2009)

[13] Wikipedia (2018) Muppandal Wind Farm, URL:https://en.wikipedia.org/wiki/Muppandal_Wind_Fa rm (date accessed: 12April 2018)

[14] Industry About (2018) Jaisalmer Wind Farm, URL: available from https:/Www.industryabout.com/country- territories-3/962-india/wind-energy/45830-jaisalmerwind-farm (date accessed: 3 February 2018)

[15] Power Technology (2018) Shepherds Flat Wind Farm, Oregon, URL:https://www.powertechnology.com/projects/shepherds-flat-wind-farmoregon/ (dateaccessed: 26 April 2018).

[16]SECI/NREDCAP/APTRANSCO - Solar-Wind Hybrid Power Plant 160 MW - Andhra Pradesh - Project Profile, December 2017.

[17] ARENA Wire, “Australia's first hybrid wind and solar farm", 2 February 2018, URL:https://arena.gov.au/blog/gullen/ (date accessed: 279 July 2018).

[18] Charlotte Tiller, "Case Study of a Large-Scale Solar and Wind Power HybridSystem at Fakken Wind Farm, Troms“, Masters Thesis Dissertation, The Arctic University of Norway, June 2017.

[19] Vaselina Petrova, , "Hero Future Energies brings live India's 1st solar-wind hybrid", Renewables Now, 23 April 2018 (date accessed: 29 July 2018).

[20] Boyle, G. (2004) Renewable Energy: Power for a Sustainable Future. Oxford University Press.

[21] Hau, E. (2006) Wind Turbines, Fundamentals, Technologies, Applications and Economics, 2nd Ed. Berlin: Springer

[22] Yashwant, S., Gupta, S.C., Bohre, A.K. and Meng, W. (2016) 'PV-wind hybrid system: A review with case study’ Cogent Engineering, 3(1), 1-31

[23] Windstream Technologies (2018) Windstream Technologies Economical Energy,URL: https://www.windstream-inc.com/products/solarmill [date accessed: 26April 2018]

[24] Tangshan TOYODA Technology, URL: http://www.wptyd.com/product/81.html (date accessed: 29 July 2018).

[25] SkyWolf Wind Turbine Corporation, URL: http://www.skywolfwindturbines.com/specifications/ (date accessed: 29 July 2018).

[26] Pierrick, I. (2016) 'Design and Test of a 3D-printed Horiontal Axis Wind Turbine', Universite Catholic de Louvain Master Thesis Dissertation, 53-54 